\title{
Art Therapy as Supportive-Expressive Therapy in Breast Cancer Treatment
}

\section{/ Art terapija kao suportivno-ekspresivna terapija u liječenju karcinoma dojke}

\author{
Lea Milutinović', Marijana Braš2,3, Veljko Đorđevićc \\ ${ }^{1}$ University of Zagreb School of Medicine, Student Society for Neuroscience, Zagreb, Croatia, ${ }^{2}$ Zagreb \\ University Hospital Centre, Department of Psychological Medicine, Zagreb, Croatia, ${ }^{3}$ University of Zagreb \\ School of Medicine, Centre for Palliative Medicine, Medical Ethics and Communication Skills, Zagreb, Croatia \\ / 'Sveučilište u Zagrebu, Medicinski fakultet, Studentsko društvo za neuroznanost, Zagreb, Hrvatska, ${ }^{2}$ Klinički \\ bolnički centar Zagreb, Klinika za psihološku medicinu, Zagreb, Hrvatska, ${ }^{3}$ Sveučilište u Zagrebu, Medicinski \\ fakultet, Centar za palijativnu medicinu, medicinsku etiku i komunikacijske vještine, Zagreb, Hrvatska
}

Aims: Art therapy as supportive-expressive therapy is gaining increasing importance in psycho-oncology. The aim of this paper is to describe the experience of participating in art therapy of a patient with breast cancer and to review the literature regarding the effectiveness of art therapy during breast cancer treatment. Methods: The participant undergoing medical treatment for breast cancer was treated at the Clinical Hospital Centre Zagreb, at the Department of Psychological Medicine. A therapeutic approach was used to analyze the patient's data. Review of the literature in the field of art therapy in psycho-oncology was done, with a particular focus on the approach to patients with breast cancer. Results: Studies have found that breast cancer diagnosis has a large impact on the emotional, cognitive and social functioning of women. It is important to develop strategies to strengthen coping mechanisms in women with breast cancer and help them express often-repressed emotions. The main point of supportive-expressive therapy includes mourning the losses that cancer brings and adapting to a changed body image. Expression in art gives emotions a form and a color instead of just the physical or psychological symptoms. Conclusion: The literature and this case show that art therapy has a lasting effect on a large spectrum of symptoms related to breast cancer and its consequences as well as on self-knowledge and self-realization of the patient. Therefore, art therapy can be used as a highly effective approach to provide breast cancer patients with better quality of life and psychological support while giving them freedom to express themselves and add meaning to their days.

/ Art terapija dobiva sve veće značenje u psihoonkologiji. Cilj ovog rada je opisati iskustvo pacijentice na kojoj se provodila art terapija te napraviti pregled literature o učinkovitosti art terapije u pacijentica s karcinomom dojke. Metode: Pacijentica koja se liječila od raka dojke liječena je i kod psihijatra u Klinici za psihološku medicine Kliničkog bolničkog centra Zagreb. Analizirani su prikupljeni podatci o pacijentici prije, tijekom i nakon terapije. Napravljen je pregled literature u području psihoonkologije s posebnim naglaskom na primjenu art terapije kod onkoloških bolesnika. Rezultati: Istraživanja su pokazala kako rak dojke značajno utječe na emocionalno, kognitivno i socijalno funkcioniranje žena. Također rezultati pokazuju kako je važno poticati mehanizme obrane kod pacijentica koje boluju od karcinoma kako bi uspjele pokazati osjećaje koji su potisnuti. Glavni ciljevi ove suportivno-ekspresivne terapije su proraditi žalovanje za gubitcima koje donosi teška bolest kao i prilagodba na promijenjenu sliku tijela. Ekspresija u umjetnosti daje simptomima formu I boju te se oni više ne moraju konvertirati u fizičke ili psihološke tegobe. Zaključak: Literaturni podatci i analiza slučaja pokazali su kako art terapija ima dugodjelujući učinak na veliki spektar simptoma vezanima uz rak dojke i njegove posljedice. Također, uočen je pozitivan utjecaj na samospoznaju i samoaktualizaciju pacijenata. Zbog toga se art terapiju može koristiti kao visoko učinkovit pristup u pružanju psihološke pomoći pacijenticama oboljelima od raka dojke, koji omogućava ekspresiju emocija i bolju kvalitetu života. 
ADDRESS FOR CORRESPONDENCE:

Marijana Braš, MD

University Department of Psychological

Medicine,

Clinical Hospital Centre Zagreb,

Kišpatićeva 12

10000 Zagreb, Croatia

Tel: +38 598223 323; Fax: +38 51233

5818

E-mail: marijana.bras@kbc-zagreb.hr
KEY WORDS / KLJUČNE RIJEČI:

Art therapy / Art terapija

Breast cancer / Rak dojke

Psycho-oncology / Psihoonkologija

Psychotherapy / Psihoterapija

\section{INTRODUCTION}

Over the past few decades, art therapy in psycho-oncology has been gaining increasing importance (1). Health care professionals are continuously exploring new creative approaches for providing psychological help to cancer patients and survivors. A person diagnosed with a malignant disease often develops overwhelming feelings that are challenging to express by usual means. A cancer diagnosis and treatment entail profound changes in people's lives that require significant adjustment and extensive coping skills (2). The diagnosis of cancer can generate great fear of pain, of dying, of economic and social changes and dependence (3). Burdened with the reality of a shortened or painfully altered life, patients have the need to channel emotions into numerous forms of expression. For patients, art therapy allow them to express what is deep inside them, emotions that cannot be communicated with words alone, while alleviating their symptoms and giving them psychological support. This paper describes and discusses effects of art therapy in patients undergoing art therapy during breast cancer treatment, through review of literature as well as a case report and analysis.

\section{ART THERAPY}

The therapeutic use of art within the context of a professional relationship with patients who have experienced disease, trauma or difficulties in their life is called art therapy (4). Creation of art can assist a person in communicating their emotional or psychological problems through the use of imagery (5). In cancer patients, from the perspective of a holistic approach, creative expression has the potential to address the mental, social, physical and spiritual issues regarding their current state. Addressing their concerns can help decrease psychological stress and have a positive impact on the immune system and overall functioning of the body $(1,2)$. Studies have shown that approximately more than one-third of cancer inpatients and a quarter of outpatients suffer from psychological comorbidity (6). Art therapy helps patients with a malignant disease express experiences that are hard or impossible to put into words and is suitable for patients with various diagnoses, ages and levels of education $(1,7,8,9)$. Review of the literature showed the significant effect of this type of psychotherapy, despite the heterogeneity in samples and study designs $(1,10,11,12,13,14,15,16)$. Several studies confirmed how art therapy helps cancer patients by reinforcing positive coping 
behavior while increasing the sense of control $(17,18,19)$. Surveys carried out by an interdisciplinary research team demonstrated statistically significant reductions in cancer symptoms with a lower score in depression, anxiety, somatic and general symptoms for the therapy group compared to the control group (20). Differences were also observed in increased efficiency in communication and relationships, processing of traumatic experiences and reduction of negative effects of disease and treatment $(12,14,15,20)$. Studies have also shown that psychological support and art therapy have a positive impact on the outcome of the cancer treatment $(21,22,23,24)$. An increase in self-esteem and cohesion, strengthening self-identity and significant improvement in global health, wasfound $(12,25)$.

Art therapy also helps patients' families and caregivers by reducing stress and decreasing anxiety $(26,27)$. Furthermore, through artistic expression, healthcare professionals can be educated to better understand the participants' emotional experiences.

\section{BREAST CANCER SYMPTOMS}

Breast cancer diagnosis has a great impact on the overall health and functioning of women (28). Associated with visible feminine aspects of the body, breast cancer represents the threat of disfigurement, disability, fear of loss of intimacy and love and reduced self-esteem (29). The medicalized breast is decontextualized from the whole of the bodies and lives of women and from their personal and cultural meanings (30). The cultural discourse of breast cancer may lead to feelings of stigma, marginalization and disempowerment. The loss or alteration of a breast poses a threat to a women's perception of self and feminine identity, especially aspects like sexuality and motherhood (31).
After surgery, chemotherapy, radiotherapy and hormone treatments, women with breast cancer describe extensive changes to their bodies, such as wounds, pains, body hair loss, extreme fatigue, nausea and vomiting, lack of appetite, lymphedema, adverse effects on the radiated skin, postmenopausal symptoms and weight problems $(1,32)$. Numerous side effects can make a woman feel alienated from her body $(29,33)$. Multiple cross-sectional studies have found that women with breast cancer report fatigue, pain, tiredness, depression, anxiety and a failing self-esteem $(34,35)$. Women with breast cancer reported significantly more insomnia, appetite loss, and diarrhea with significantly lower scores related to emotional, cognitive and social functioning compared with the general population (36). The scores were measured at the time of the diagnosis and one year after the operation. Nearly half of women with early breast cancer have depression, anxiety or both depressive and anxious symptoms during the first year after diagnosis (24).

Women with breast cancer often report feelings of fear as well as loneliness. They describe that other people do not know how to communicate with them and share their concerns. A standard issue is worrying about the people around them being too emotionally involved. Constant efforts to spare other people's feelings can cause isolation in women with breast cancer $(1,37,38)$. Repressed emotions have a huge role in dealing with cancer treatment, so it is important to develop strategies to strengthen coping resources in women with breast cancer and help them express oftenrepressed emotions $(39,40)$.

\section{BREAST CANCER AND ART THERAPY}

Art therapy has been found to help confront experiences of loss, physical changes, social relations affecting and existential questions 
in women with breast cancer $(16,41,42)$. A randomized controlled study, as well as other studies, showed a significant increase in total health, physical and psychological states and improved quality of life during art therapy in women undergoing cancer treatment (1). Studies demonstrated a significant positive difference within the art therapy group concerning future perspectives, body image and systemic therapy adverse effects as well as decreased levels of stress and improved self-esteem and overall health $(1,25,43)$. Additionally, art therapy has an effect on overcoming feelings of hopelessness and gaining control over the situation (25). Improvement in relationships, specifically in communication with family and friends after taking part in art therapy, has been demonstrated (13). Art therapy could offer an opportunity for women with cancer to describe their experiences and give these interpretations acceptance and legitimacy. That may translate into a greater sense of control in the new life situation (44).

\section{PROCESS OF ART THERAPY}

The fundamental belief on which the use of art therapy is based on is that the creative process in the creation of art is life-improving and healing and that it relieves symptoms associated with cancer (41). Art creation has been said to facilitate expression of an individual's deepest emotions (11). Art therapy is regarded as psychotherapy that can be used for processing the emotional trauma and stress (45). It can help patients recover hope and develop goals and discover that they want to have a fulfilled life despite the diagnosis (37). The focus of supportive-expressive therapy includes mourning the losses that cancer brings and adapting to a changed body image (35). Creation of art and reflecting on the process and outcome can enhance patients' awareness of self and others, induce better coping with symptoms, stress and trauma and improve cognition (46). The art object in art therapy helps the patient to hold onto a sense of self while at the same time working with potentially distressing feelings. The objects represent a form of communication between the therapist and the patient, creating a language for the unconscious and unknown to become conscious and to mobilize deepening self-awareness and therapeutic change. Cognitive analytic therapy supports change through various processes. However, a central route is through "knowing". Art therapy also creates change in different ways, but the primary way is by "working through", i.e. the emotional processing of past events which allows further development (5). The therapy process stimulates the neurons in various ways. First, during the movement of the body in the process of painting, which physically expresses emotions that are reaffirmed in the reflection on a product or image, and in the relation between patient and therapist (35). The process is a psycho-educational and psychodynamic, helping ego and unconscious material to be integrated. It takes action and reflection in art therapy to promote the participant's process of self-understanding in the current situation $(5,35)$. Furthermore, understanding the vulnerability of oncology patients and being able to address their needs is essential for any therapeutic intervention to be successful. Thus, it is important for the art therapist to help patients overcome their apprehension and to feel comfortable. When the patient's goals are the guiding factor in the art therapy session, the art therapist needs to be vigilant to notice if and when these intentions change. Repressed emotions, especially anger, appear to be one of the risk factors for cancer (47). It may be that this population of patients is more inclined to avoid self-expression than other groups. Often, underlying feelings triggered by the process of art making can cause a shift in the focus of the session. What starts out as a distraction from problems re- 
lated to cancer can become an outlet for more profound emotions. In this situation, the art therapist's experience and knowledge of therapeutic techniques and understanding of metaphor allow the patient to process the complex issues that emerge (8). Regression analysis suggested that creative expressions give the somatic symptoms a form and a color instead of just the physical or psychological symptoms (48). In art therapy, the picture lasts. It can be focused and felt and be seen and touched as well as moved (49). The picture is there in relation to feelings and thoughts, even afterwards, like a transitional phenomenon (50). In the art therapy sessions, the painter can always look at their own expression in forms, figures, lines and colors to recognize different emotions and thoughts from time to time and to identify emotional or cognitive alterations on the paper. It is believed that the mirror neurons provide intersubjective consciousness that aims to internalize the therapeutic relationship to give the patient a new pattern to relate to oneself or the picture and others, such as the therapist $(35,51)$. The process promotes the patient's understanding of self and the current situation (52).

\section{CASE ANALYSIS}

In this article, we share the remarkable story of the patient M.S., who participated in art therapy during and after her illness as a form of expressing herself and a coping mechanism for severe mental and emotional distress. Although she painted and wrote poems and novels her whole life, the disease inspired her creative forces in an entirely new way. Learning about her experience influenced and encouraged all the members of our medical team, including doctors, students and other patients. The painting was started after she received the diagnosis of malignant disease. She painted daily, sometimes even five paintings a day, and by the end of treatment, she painted about 200 pictures. After the treatment, she had written diaries in which she described the psychological states that she was in during past events and emotions she was experiencing before, after and during the painting process. During treatment, she sought a psychiatrist, was in a psychiatric day hospital and participated in support groups for women suffering from breast cancer. After the end of treatment and with the help of a psychiatrist, she published an exhibition of the pictures and their analyses and records from the diaries after the process of therapy.

Using art expression significantly contributed to psychotherapy and facilitated the cancer therapy of the patient. The patient began to paint because she wanted her own space and a safe place, a place in which she felt free. She felt like a frightened child, and painting helped her to feel secure, like being in a mother's womb again. When asked about the pictures, the patient stated that they were made spontaneously and without advance planning, and the through them, she learned about herself. She believed that she had repressed emotions for a large part of her life and that painting helped her come in contact with them, recognize them and express them. After diagnosis, she described feelings of being trapped in her body, horror, despair, loneliness, irreconcilability of diagnosing and denial, exhausting fear, paralyzing thoughts and an inability of normal functioning, all of which she was unable to express and communicate to other people. She believed that she was not able to cope with negative emotions before the art therapy, that she only suppressed and rejected them and that the painting helped her to free them through creative work, writing and conversation with a therapist and other people. During the process of art therapy, she became capable of talking about the problems that she had with herself, the disease, treatment and 
outcome of cancer. With the help of a therapist, she recognized the fear of rejection and also came back into contact with the trauma of abuse suffered in early childhood, as well as the trauma with her ex-husband.

The paintings restored balance in her life, provided psychological and emotional support and reduced her poor moods, and she began to notice more positive things in life and focus more on introspection. After diagnosis, when she felt like she was losing control of her life and mental condition, painting gave her back a sense of control, hope and desire to live. She accepted the transience of life and the inevitability of death, while valuing life more. She stated that her psychic structure had changed, and had, with apparent growth and development, become more tolerant, wiser, compassionate and altruistic. Of somatic symptoms, she had nausea, vomiting, pain in the arm on the side where the operation has been and headaches. She painted when she was in pain, and after painting the pain was eased in the hand and shoulder and as well as in the head. After the treatment, she continued to paint and says that she now paints pictures that are completely different from those she painted then. When looking at the old pictures, she recalls the emotions of that time that are now gone. The patient would recommend this kind of treatment and psychiatric help to all patients who undergo a similar experience.

\section{CONCLUSION}

Studies found that cancer patients expressed difficulty in coping and adapting to the disease (35). Art therapy significantly improved patients coping strategies. One of the purposes of art therapy is to make, through alleviation of symptoms, pain, sorrow and suffering more bearable. Art therapy can be a vehicle for the expression of the pre-verbal and non-verbal impression (5). Our patient, in her words, found relaxation, solace, calm, catharsis and healing in the process of painting, as well as strength to fight a disease and continue with an extremely severe cancer therapy. We also looked at the effect of art therapy on relieving symptoms of cancer and side effects of cancer treatment, such as pain in the right arm after breast surgery, fatigue, nausea, headache, depression and anxiety. The patients reported that the art therapy increased the will to live, the desire for healing and effectiveness in communication in relationships and social functioning. Furthermore, art therapy increased the motivation of the patient to engage inpainful and intimate content and explore unconscious conflicts, as well as the will to use that material in the therapeutic process with the therapist. During the process of art therapy, our patient was inspired to talk openly about her problems, including the trauma in her childhood and trauma with her ex-husband. Restoration of positive defense mechanisms can increase self-confidence and sense of control and expression of repressed emotions and conflicts without using words. Through her art, she found the way to see herself, her history, physical and mental health and disease in a liberating and different way. She got in touch with her emotions and traumas and overcame them, which helped her with mental and physical healing and emotional stability. This facilitating potential of art therapy can be advantageous for those whose difficulties are emotionally dissociated or repressed for whatever reason (5). The unconscious achieves expression through images in a way that it does less readily through words. The layers of possible meanings found in artwork can assist elaboration of a sense of self. Patients also advanced significantly in personal growth, self-expression, self-actualization and communication with the therapist as well as with family members and friends. Artworks helped with the development of a reflective self, non-verbal communication 

apy has a lasting effect on a large spectrum of how to see things in different ways.

"Painting made me feel like I am still able to create something great, that I'm not just a person with cancer. During the process of painting I felt safe and secure as if I was a child in my mother's womb again. I wasn't thinking about the disease. The disease was becoming smaller and smaller as my feeling of self-worth grew bigger and stronger." symptoms related to breast cancer and its consequences as well as on self-knowledge and self-realization of the patient, while improving the overall quality of life. Furthermore, art creation encourages vision, hope and imagination, all of which nurture the healing process (4). Therefore, art therapy can be used as a highly effective approach to give our patients the best quality of life, give psychological support while giving them freedom to express themselves and add meaning to their days.

\section{REFERENCES}

1. Svensk AC, Öster I, Thyme KE. Art therapy improves experienced quality of life among women undergoing treatment for breast cancer: a randomized controlled study. Eur J Cancer Care 2009; 18: 69-77.

2. Geue $K$, Richter $R$, Buttstadt $M$. An art therapy intervention for cancer patients in the ambulant aftercare - results from a non-randomised controlled study. Eur J Can Care 2013; 22: 345-52.

3. Moschén R, Kemmler G, Schweigkofler $\mathrm{H}$ et al. Use of alternative/complementary therapy in breast cancer patients - a psychological perspective. Support Care Cancer 2001; 9: 267-74.

4. Loi C. An analysis of artwork representing the experiences of colorectal cancer survivors. Nurs J Singapore 2011; 38: 4-5.

5. Hughes R. An enquiry into an integration of cognitive analytic therapy with art therapy. Int J Art Ther 2007; 12: 28-38.

6. Gil Moncayo FL, Costa RG, Perez FJ, Salamero M, Sanchez N, Sirga A. Adaptación psicológica y prevalencia de trastornos mentales en pacientes con cáncer. Med Clin (Barc) 2008; 130: 90-2.

7. Stuckey HL, Nobel J. The connection between art, healing, and public health: a review of current literature. Am J Public Health 2010; 100: 254-63.

8. Nancy A, Nainis MAAT. Approaches to Art Therapy for Cancer Inpatients: Research and Practice Considerations. Art Ther 2008; 25: 115-21.

9. Goetze H, Geue K, Buttstaedt M, Singer S, Schwarz R. Art therapy for cancer patients in outpatient care. Psychological distress and coping of the participants. Res Com Med 2009; 16: 28-33.

10. Pratt M, Wood M. Art Therapy in Palliative Care. London: Routledge, 1998.

11. Malchiodi CA. Medical Art Therapy with Adults. London: Jessica Kingsley Publishers, 1999.

12. Luzzatto P, Gabriel B. The creative journey: a model for short-term group art therapy with posttreatment cancer patients. Am J Art Ther 2000; 17: $265-69$.

13. Gabriel B, Bromberg E, Vandenbovenkamp J, Walka P, Kornblitz B, Luzzatto P. Art therapy with adult bone marrow transplant patients in isolation: a pilot study. Psychooncology 2001; 10: 114-23.

14. Borgmann E. Art therapy with three women diagnosed with cancer. Arts Psychother 2002; 29: 245-51.

15. Luzzatto P, Sereno V, Capps R. A communication tool for cancer patients with pain: the art therapy technique of the body outline. Palliat Support Care 2003; 1: 135-42.

16. Waller D, Sibbett C. Art Therapy and Cancer Care. London: Open University Press, 2005.

17. Breslow DM. Creative arts for hospitals: The UCLA experiment. Patient Edu Couns 1993; 21: 101-10.

18. Heiney SP, Darr-Hope H. Healing Icons: Art support program for patients with cancer. Canc Pract 1999; 4: 183-89.

19. Peace $G$, Manasse A. The Cavendish Centre for integrated cancer care: Assessment of patients' needs and responses. Complementary Therapies in Medicine 2002; 10: 33-41.

20. Nainis NA, Paice JA, Ratner J, Wirth J, Lai J, Shott S. Relieving symptoms in cancer: Innovative use of art therapy. J Pain Symptom Manage 2006; 31: 162-69.

21. Spiegel D, Bloom JR, Kraemer HC. Effect of psychosocial treatment on survival of patients with metastatic breast cancer. Lancet 1989; 2: 888-91.

22. Spiegel D. Psychosocial aspects of breast cancer treatment. Semin Oncol 1997; 24: 1-36.

23. Badger TA, Braden CJ, Mishel MH. Depression burden, psychological adjustment and quality of life in women with breast cancer: Patterns power time. Res Nurs Health 2004; 27: 19-28.

24. Burgess C, Cornelius V, Love S. Depression and anxiety in women with early breast cancer; five year observational cohort study. BMJ 2005; 330: 702-5.

25. Reynolds MW, Nabors L, Quinlan A. The effectiveness of art therapy: Does it work? Am J Art Ther 2000, 17, 207-13. 
26. Walsh SM, Martin SC, Schmidt LA. Testing the efficacy of a creative-arts intervention with family caregivers of patients with cancer. J Nurs Schol 2004; 36: 214-19.

27. Walsh SM, Weiss S. Online exclusive: Art intervention with family caregivers and patients with cancer. Oncol Nurs Forum 2003; 30: 115-20.

28. Thewes B, Butow P, Girgis A, Pendlebury S. Assessment of unmet needs among survivors of breast cancer. J Psychosoc Oncol 2004; 22: 51-73.

29. Bassett-Smith J. Women with breast cancer and their living in and through discourses: a feminist post-modern study. Dissertation for the degree of Doctor of Philosophy in the School of Nursing. University of Victoria, Canada, 2001.

30. Langellier KM, Sullivan CF. Breast talk in breast cancer narratives. Qual Health Res 1998; 8: 76-94.

31. Thibeault C, Sabo BM. Art, archetypes, and alchemy: images of self following treatment for breast cancer. Eur J Oncol Nurs 2012; 2: 153-7.

32. Oster I, Svensk AC, Magnusson E. Art therapy improves coping resources: a randomized, controlled study among women with breast cancer. Palliat Support Care 2006; 1: 57-64.

33. Manderson L. Gender, normality and the postsurgical body. Anthropology and Medicine 1999; 6: 381-94.

34. Nainis NA. Approaches to art therapy for cancer inpatients: research and practice considerations. Art Ther 2008; 25: 115-21.

35. Thyme KE, Sundin EC, Wiberg B. Individual brief art therapy can be helpful for women with breast cancer: a randomized controlled clinical study. Palliat Support Care 2009; 1: 87-95.

36. Schou I, Ekeberg Ö, Sandvik L, Hjermstad JM, Ruland CM. Multiple predictors of health-related quality of life in early stage breast cancer. Data from a year follow-up study compared with the general population. Qual Life Res 2005; 14: 1813-23.

37. Serlin IA, Classen C, Frances B, Angell K. Symposium: support groups for women with breast cancer: traditional and alternative expressive approaches. Art Psychother 2000; 27: 123-38.

38. Adamsen L, Rasmusen JM. Exploring and encouraging through social interaction. Cancer Nurs 2003; 26: 28-36.

39. Boman L, Andersson JU, Björvell H. Needs as expressed by women after cancer surgery in the setting of a short hospital stay. Scand Uni Press $1997 ; 11: 25-32$.

40. Koopman C, Angell K, Turner-Cobb JM. Distress, coping, and social support among rural women recently diagnosed with primary breast cancer. Breast J 2001; 7: 25-33.

41. Predeger E. Woman spirit: a journey into healing through art in breast cancer. Adv Nurs Sci 1996; 18: 48-58.

42. Malchiodi CA. Invasive art: art as empowerment for women with breast cancer. In: Hogan S (ed). Feminist Approaches to Art Therapy. Routledge, 1997, 49-64.

43. Monti DA, Peterson C, Shakin Kunkel EJ et al. A randomized controlled trial of mindfulness-based art therapy (MBAT) for women with cancer. Psychooncology 2006; 15: 363-73.

44. Heywood K. Introducing art therapy into the Christie Hospital Manchester UK 2001-2002. Com Ther Nurs Midwifery 2003; 9: 125-32.

45. Suzuki N. Complementary and alternative medicine: A Japanese perspective. Evid Based Complement Alternat Med 2004; 1: 113-18.

46. Edwards D. Art therapy. London: SAGE Publications Ltd, 2014.

47. Richardson MA, Sanders T, Palmer JL, Greisinger A, Singletary SE. Complementary/alternative medicine use in a comprehensive cancer center and the implications for oncology. J Clin Oncol 2000; 13: 2505-14. 47

48. McDougall J. The Theatres of the Body. London: Free Association Books, 1989.

49. Schaverien J. The Revealing Image. London: Routledge, 1992.

50. Winnicott DW. Playing and Reality. London: Tavistock, 1971.

51. Lukowski AF, Wiebe SA, Haight JC. Forming a stable memory representation in the first year of life: why imitation is more than child's play. Dev Sci 2005; 8: 279-98.

52. Sugerman A. Mentalization, insightfulness, and therapeutic action. Int J Psychoanal 2006; 87: 965-87. 